\title{
Synergistic cytotoxic effect of sulindac and pyrrolidine dithiocarbamate against ovarian cancer cells
}

\author{
ANNA JAKUBOWSKA-MUĆKA ${ }^{1}$, JACEK SIENKKO ${ }^{2}$, ŁUKASZ ZAPAŁA ${ }^{3}$, RAFAŁ WOLNY ${ }^{3}$ and WITOLD LASEK ${ }^{3}$ \\ ${ }^{1}$ Department of Immunology, Maria Skłodowska-Curie Memorial Cancer Center and Institute of Oncology, Warsaw; \\ ${ }^{2}$ Second Clinic of Obstetrics and Gynecology, Medical University of Warsaw, Warsaw; ${ }^{3}$ Department \\ of Immunology, Centre of Biostructure, Medical University of Warsaw, Warsaw, Poland
}

Received October 10, 2011; Accepted December 1, 2011

DOI: $10.3892 /$ or.2012.1639

\begin{abstract}
Sulindac, a non-steroidal anti-inflammatory drug, suppresses carcinogenesis and inhibits growth of tumor cells. Pyrrolidine dithiocarbamate (PDTC), a potent NF- $\kappa \mathrm{B}$ inhibitor, has been also identified as a potential anti-neoplastic agent. We hypothesized that combination of sulindac and PDTC could result in augmentation of cytotoxicity against ovarian cancer cells. The effect of sulindac and PDTC was examined on several ovarian cancer lines. Tumor cell viability was assessed using the MTT assay. Annexin-V/PI staining was used to detect apoptosis, cell cycle distribution was analyzed in FACS, and expression of cellular proteins was detected by Western blotting. Incubation of OVA-14, OVP-10 and CAOV-1 ovarian cancer cells with sulindac and PDTC resulted in significantly greater inhibition of cell viability compared to either compound alone. In a model of OVA-14 cells it was evident that this effect was not related to the expression of COX enzymes since both active (sulindac sulfide) and inactive (sulindac) in vitro compounds affected the growth of tumor cells to a similar extent and synergized in cytotoxicity with PDTC. Combination of sulindac and PDTC lead to G0 arrest and massive apoptosis in co-treated cultures. Western blotting analysis argued for induction of the mitochondrial apoptotic pathway. These data demonstrate the synergistic cytotoxic effect of sulindac and PDTC on ovarian cancer cells through apoptosis and cell cycle arrest and prompt to test the efficacy of this combination in animal models.
\end{abstract}

\section{Introduction}

Ovarian cancer is the most deadly malignancy of the female reproductive system with more than $70 \%$ of cases diagnosed

Correspondence to: Dr Witold Lasek, Department of Immunology, Centre of Biostructure Research, Medical University of Warsaw, Banacha 1a Street, F building, 02-097 Warsaw, Poland

E-mail: witold.lasek@wum.edu.pl

Key words: sulindac, pyrrolidine dithiocarbamate, ovarian cancer, apoptosis at an advanced stage. Current treatment of this cancer includes cytoreductive surgery (tumor debulking) followed by platinum- and taxane-based therapy (1). However, despite a high rate of initial remissions, patients usually relapse and subsequently require additional second- or third-line therapy $(2,3)$. Unfortunately, the patients eventually develop drug resistance, causing limitations of further treatment options and decreasing overall survival (1). Thus, intervention with chemopreventive agents or new adjuvant therapy may offer a desirable option for ovarian cancer (4).

Experimental studies, animal tumor models and many in vitro experiments have all demonstrated that non-steroidal anti-inflammatory drugs (NSAIDs) appear to be effective in chemoprevention and possible treatment of various types of cancer (5-10). The rationale of their use is their cyclooxygenases (COXs)-blocking activity. Overexpression of COX genes is a frequent phenomenon in preneoplastic and tumor tissues, including ovarian cancer (9), and is recognized as a bad prognostic factor. Upregulation of the COX enzymes in ovarian tumor cells has been implicated in platinum drug resistance and promotion of tumor progression $(11,12)$. However, some studies suggest that overexpression of COXs is not obligatory for anticancer effect, at least in therapeutic approach, and NSAIDs can directly kill tumor cells via different intracellular pathways including NF- $\kappa \mathrm{B}$ inhibition $(10,13,14)$.

One of the most promising pharmaceutical agent from the group of NSAIDs, reported to inhibit carcinogenesis and acting directly against tumor cells in vitro and in experimental tumor models, is sulindac. This agent itself does not inhibit cyclooxygenases but is metabolized to COX-inhibiting sulindac sulfide and inactive sulindac sulfone. Sulindac and its derivatives, alone or in combination with some chemotherapeutics, have been found to induce growth suppression and apoptosis in cultures of tumor cells (15-22), including ovarian cancer (23). At present, sulindac is being evaluated as a chemopreventive or therapeutic agent in several clinical trials (NCT00755976, NCT00299195 and NCT00118365 available at http:/www. clinical trials.gov). There are also attempts to use sulindac sulfone, known as exisulind, in combination treatments of various types of cancer $(24,25)$.

Pyrrolidine dithiocarbamate (PDTC) is a thiol-containing synthetic compound, which is known for its antioxidant, metal-chelating and strong $\mathrm{NF}-\kappa \mathrm{B}$ inhibitory properties 
$(26,27)$. Occasionally, it exerts paradoxical prooxidant activity (28). Recently, PDTC has attracted the attention of investigators as a potential anticancer agent. In in vitro studies this agent exerted cytotoxic effects against many types of cancer cells (28-30). Interestingly from the therapeutic point of view, PDTC has been shown to inhibit blood vessel formation and tumor angiogenesis in ex vivo studies and in animal models (31).

In a previous study, we have demonstrated that sulindac and sulindac sulfide but not other NSAIDs such as acetylsalicylic acid and rofecoxib inhibited the growth of various ovarian cancer cells (32). We supposed that this effect could result from NF- $\kappa B$ targeting. The aim of the present study was: i) to assess the effect of sulindac or sulindac sulfide in combination with PDTC on the growth of cells of different ovarian cancer lines; and ii) to identify possible mechanisms of their action.

\section{Materials and methods}

Cell cultures. The following ovarian cancer cell lines were used in the study: OVA-14 (established in our laboratory from solid epithelial (serous) tumor, CAOV-1 (obtained from Dr M. Siedlar, Jagiellonian University Collegium Medicum, Krakow), OVP-10 (obtained from Dr B. Szaniawska, Institute of Oncology, Warsaw), MDAH 2774 (ATCC no. CRL-10303), SKOV-3 (ATCC no. HTB-77). The cells were grown in Dulbecco's modified Eagle's medium (DMEM, Gibco-BRL, Invitrogen) (OVA-14, CAOV-1, MDAH 2774, SKOV-4) or RPMI-1640 (Gibco-BRL, Invitrogen) (OVP-10) supplemented with $10 \%$ heat-inactivated fetal calf serum (FCS, Gibco-BRL, Invitrogen) and antibiotic-antimycotic (Sigma). The cells were maintained in $25-\mathrm{cm}^{2}$ tissue flasks (Nunc, Roskdile, Denmark) at $37^{\circ} \mathrm{C}$ in a humidified atmosphere of $5 \% \mathrm{CO}_{2}$ and were passaged two to three times weekly.

Drugs. Sulindac was from Sigma and sulindac sulfide was purchased from Biomol Research Laboratories (Plymouth Meeting, PA, USA). The drugs were dissolved in dimethylsulfoxide (DMSO; Sigma) and stock solutions were prepared (200 mM) for further preparation. The cells in control cultures were incubated either without diluent or with $0.1 \%$ DMSO; no significant differences in cell growth were observed. Pyrrolidine dithiocarbamate (PDTC) was purchased from Sigma, with the stock solution $(200 \mathrm{mM})$ prepared in distilled water.

MTT assay. The cytotoxic effects of sulindac and/or PDTC on ovarian cancer cells was tested in a standard 3-(4,5-dimethylthiazol-2-yl)-2,5-diphenyltetrazolium bromide (MTT) assay. This assay relies on the ability of viable cells to reduce a yellow MTT to a purple formazan product. Cells were incubated in 96 -well plates $\left(2 \times 10^{4} / 200 \mu \mathrm{l} /\right.$ well) with PDTC (final concentrations: $1,2,4,8$ and $16 \mu \mathrm{M}$ ) and sulindac or sulindac sulfide (final concentrations: 50, 100 and $200 \mu \mathrm{M}$ ), alone or in combination, for $24 \mathrm{~h}$. At the end of the incubation, $25 \mu \mathrm{l}$ of MTT $(2.5 \mathrm{mg} / \mathrm{ml})$ was added to each well for the last $4 \mathrm{~h}$. Then the cells were centrifuged ( $350 \mathrm{x} \mathrm{g,} 10 \mathrm{~min}$ ), supernatants were removed and the formazan product was dissolved in acid DMSO. The plates were read on an ELISA reader (SLT-Labinstruments, Salzburg, Austria) using a $550 \mathrm{~nm}$ filter.
A

Sulindac + PDTC

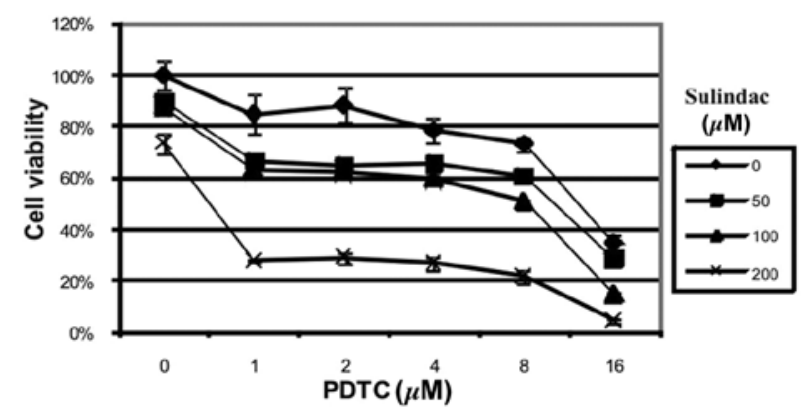

B

Sulindac sulifide + PDTC

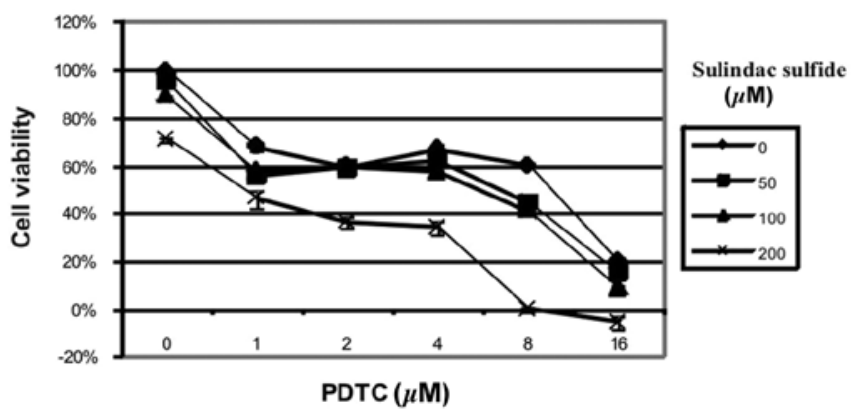

Figure 1. Effect of PDTC and sulindac (A) or sulindac sulfide (B) on viability of OVA-14 ovarian cancer cells. OVA-14 cells were incubated for $24 \mathrm{~h}$ with 1 , $2,4,8$ or $16 \mu \mathrm{M}$ of PDTC in combination with 50,100 or $200 \mu \mathrm{M}$ of sulindac or sulindac sulfide. Cell viability was measured by MTT assay. The data show the mean $\pm \operatorname{SD}(n=3)$. Strong synergistic effect is exhibited especially in cultures incubated with $200 \mu \mathrm{M}$ sulindac or sulindac sulfide with $16 \mu \mathrm{M}$ PDTC $(\mathrm{CI}<0.01$ and $\mathrm{CI}<0.4$, respectively).

The means and standard deviations were determined for triplicate samples. The cytotoxic effect was expressed as the relative viability and was calculated as follows: relative viability $=$ [(experimental absorbance - background absorbance)/(absorbance of vehicle-treated cells - background absorbance) x 100 .

Western blot analysis. At the end of incubation with sulindac \pm PDTC $(1$ or $4 \mathrm{~h})$, OVA-14 cells were washed three times in PBS and were lysed with RIPA buffer containing protease inhibitor cocktail (PMSF $0.1 \mathrm{mg} / \mathrm{ml}$, aprotinin $1.7 \mathrm{mg} / \mathrm{ml}$, pepstatin $5 \mu \mathrm{g} / \mathrm{ml}$, leupeptin $5 \mathrm{mg} / \mathrm{ml}$, sodium orthovanadate $1 \mathrm{mM}$ ) (protease inhibitor cocktail:RIPA buffer, 1:100). The protein concentration in the lysates was determined by Lowry's method. The cell extract was separated by $10 \%$ gel

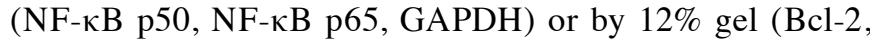
Bax, procaspase-9) and transferred onto a nitrocellulose membrane (Bio-Rad Laboratories). The membrane was blocked with 5\% non-fat milk in TBST ( $25 \mathrm{mM}$ Tris, pH 7.6, $138 \mathrm{mM} \mathrm{NaCl}$ and $0.05 \%$ Tween-20) for $1 \mathrm{~h}$ and probed with primary antibodies against: NF- $\kappa \mathrm{B}$ p50, NF- $\kappa \mathrm{B}$ p65, Bcl-2, Bax, procaspase-9 p35 (Santa Cruz Biotechnology, Santa Cruz, CA), and GAPDH (Chemicon International). After 3 washes, the membrane was further incubated with secondary antibody conjugated with horseradish peroxidase (HRP). The expression of targeted proteins was detected with the enhanced chemiluminescent (ECL) detection system (Amersham, Buckinghamshire, UK). 


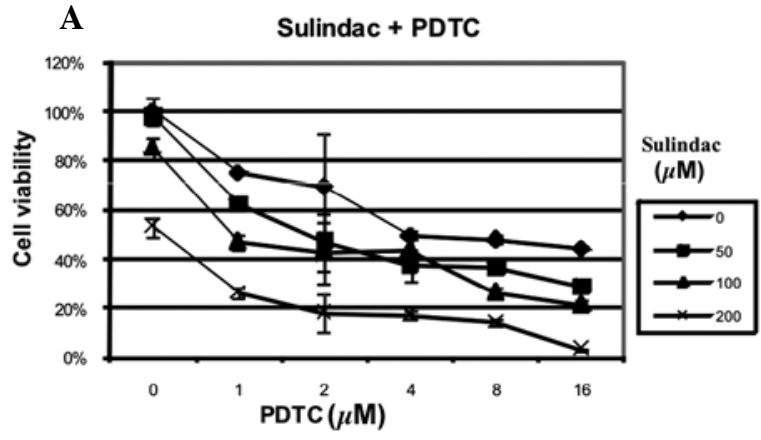

C

Sulindac + PDTC
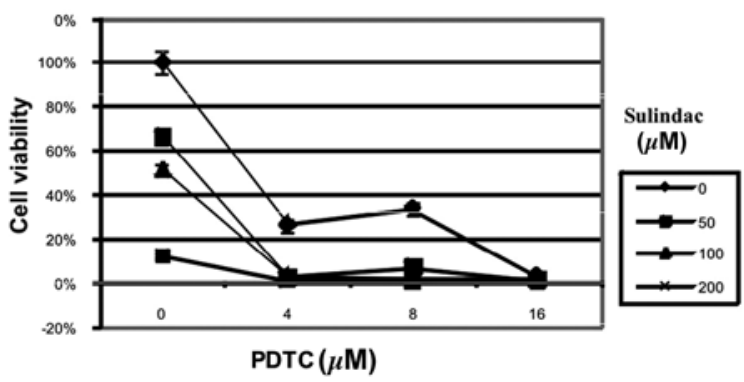

A - OVP-10, B - SKOV-3, C - CAOV-1, D - MDAH 2774

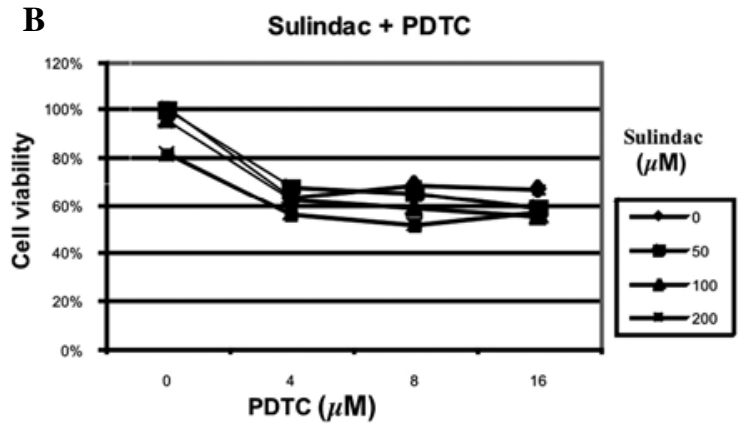

D

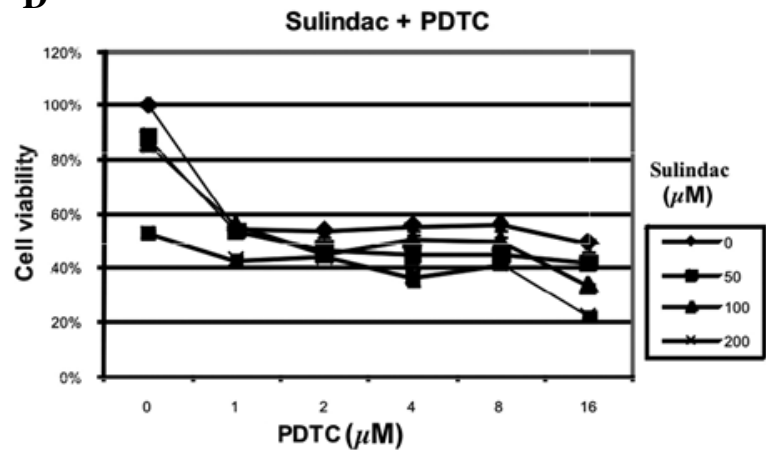

Figure 2. Effect of PDTC and sulindac on the cell viability of different ovarian cancer cell lines: (A) OVP-10, (B) SKOV-3, (C) CAOV-1 and (D) MDAH 2774 The cells were incubated with different concentrations of sulindac and/or PDTC for $24 \mathrm{~h}$ and cell viability was measured by MTT assay. The data show the mean $\pm \operatorname{SD}(n=3)$.

Apoptosis assay. Analysis of apoptosis was performed using Annexin V-FITC Apoptosis Detection KIT I (BD Pharmingen). Briefly, OVA-14 cells were incubated with sulindac $(100 \mu \mathrm{M})$ and PDTC $(16 \mu \mathrm{M})$, either alone or in combination, for 4 or $24 \mathrm{~h}$. At the end of the incubation the cells were trypsinized, washed twice with cold PBS and then resuspended in binding buffer at a concentration of $1 \times 10^{6}$ cells $/ \mathrm{ml}$. Cell suspensions $\left(1 \times 10^{5}\right.$ cells in $\left.100 \mu \mathrm{l}\right)$ were transferred to 5 -ml tubes, mixed with $5 \mu \mathrm{l}$ FITC Annexin-V and $5 \mu \mathrm{l}$ propidium iodide (PI), vortexed, and incubated for $15 \mathrm{~min}$ at room temperature in the dark. Next, $400 \mu \mathrm{l}$ of binding buffer was added to each tube and the samples were measured using a flow cytometer (FACSCalibur; Becton-Dickinson, Mountain View, CA) and CellQuest software.

Flow cytometric analysis of cell cycle. OVA-14 cells were cultured with sulindac $(100 \mu \mathrm{M})$ and PDTC $(16 \mu \mathrm{M})$, either alone or in combination, for $24 \mathrm{~h}$. The cells were then trypsinized, washed twice in PBS and fixed $\left(\sim 1 \times 10^{6}\right)$ in $3 \mathrm{ml}$ of $70 \%$ ethanol $\left(-20^{\circ} \mathrm{C}\right)$. After incubation at $-20^{\circ} \mathrm{C}$ for $48 \mathrm{~h}$, cells were washed three times in PBS and stained with $50 \mu \mathrm{g} / \mathrm{ml}$ propidium iodide (PI) and $25 \mathrm{mg} / \mathrm{ml} \mathrm{RNase}$ in PBS for $30 \mathrm{~min}$ in dark at room temperature. The samples were analyzed using a flow cytometer (FACSCalibur) and the CellQuest software.

Statistical analysis. Data are presented as mean \pm standard deviation (SD). Results of MTT assay were analyzed by the Student's t-test. Additionally, the nature of the interaction between tested drug combinations was analyzed by the method described by Chou and Talalay (33). The combination index (CI) method is a mathematical and quantitative evaluation of a two-drugs pharmacological interaction. Using data from the cytotoxicity experiments and CalcuSyn ver. 2.0 software (Biosoft, Cambridge, UK), CI values were generated. CIs of $<1$ indicate synergism, CIs $=1$ indicate additivity, and CIs $>1$ indicate antagonism.

\section{Results}

Combinations of sulindac or sulindac sulfide with PDTC synergistically inhibit the growth of OVA-14 cells in vitro. In our preliminary experiments, sulindac and sulindac sulfide were the most effective agents, from amongst other COX-1/ COX-2 inhibitors (including acetylsalicylic acid, rofecoxib, and sulindac sulfone), in inhibition of the viability of various ovarian cancer cell lines (32). To determine if effectiveness of these two agents could be enhanced by PDTC we incubated OVA-14 ovarian cancer cells with different concentrations of these compounds for $24 \mathrm{~h}$. As measured in the MTT assay, both sulindac and sulindac sulfide synergized in the cytotoxic effect with PDTC (Fig. 1). For example, incubation with $200 \mu \mathrm{M}$ sulindac resulted in $72 \%$ viability, $16 \mu \mathrm{M}$ PDTC resulted in $37 \%$ viability, and the combination of these two doses of drugs reduced viability of tumor cells below 5\% (Fig. 1A) (CI $<0.003)$. The synergistic effect of sulindac and PDTC was also manifested in CAOV-1 and OVP-10 cell cultures. MDAH 2774 and SKOV-3 cells were found to be susceptible to sulindac or PDTC but the combination of these two agents did not result in synergy (Fig. 2).

The combination of sulindac with PDTC results in cell cycle arrest. To evaluate the effects of sulindac and PDTC on cell cycle behavior, cell cycle analysis by FACS was performed. We found that incubation of OVA-14 cells with $100 \mu \mathrm{M}$ 

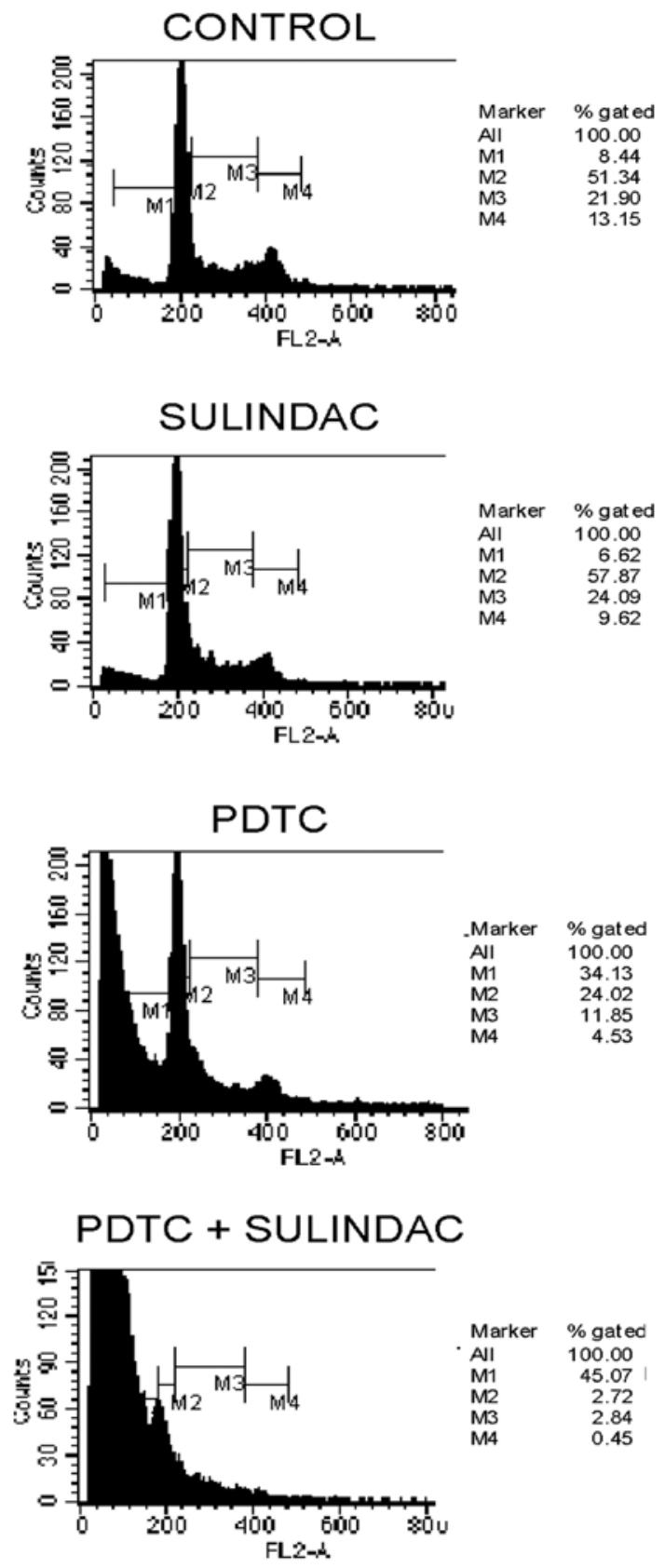

Figure 3. Effect of sulindac and PDTC on the cell cycle in OVA-14 cells. The cells were incubated with $100 \mu \mathrm{M}$ sulindac and/or $16 \mu \mathrm{M}$ PDTC for $24 \mathrm{~h}$, fixed in $70 \%$ ethanol, stained with propidium iodide, and analyzed for cell cycle distribution by flow cytometry.

sulindac did not influence cell cycle progression (Fig. 3). On the other hand, $16 \mu \mathrm{M}$ PDTC induced inhibition of a cell cycle in the sub-G1 and G0/G1 phases. Combination treatment with sulindac and PDTC, however, resulted in the strongest inhibitory effect and a dramatic increase of cell number in a sub-G1 phase; only $5 \%$ of the cells progressed to the G0/G1 + M + G2 phases (Fig. 3).

The synergistic cytotoxic effect of sulindac and PDTC can be attributed to apoptosis. To determine if decreased viability of OVA-14 cells in cultures with sulindac and PDTC result from apoptosis or other mechanisms, the cells were incubated with $100 \mu \mathrm{M}$ sulindac and $16 \mu \mathrm{M}$ PDTC, either alone or in combina-

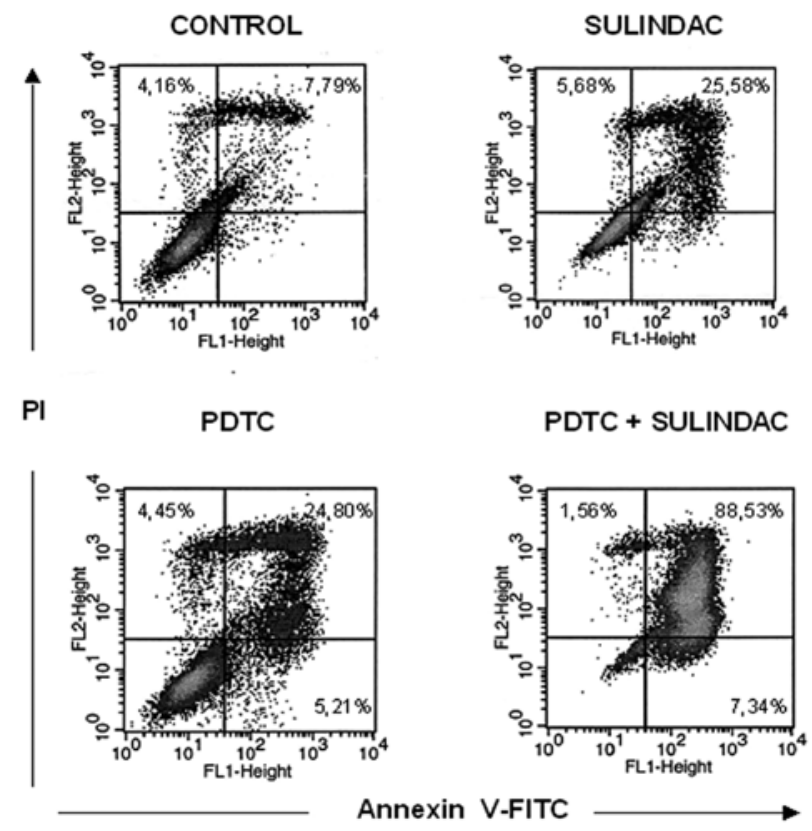

Figure 4. Annexin-V/PI dual staining of OVA-14 cells incubated with $100 \mu \mathrm{M}$ sulindac and/or $16 \mu \mathrm{M}$ PDTC for $24 \mathrm{~h}$. Numbers express the percentage of cells that were double-stained, single-stained or unstained with Annexin-V and propidium iodide. The lower right quadrant represent early apoptosis and the upper right quadrant (double-stained cells) late apoptosis cells.

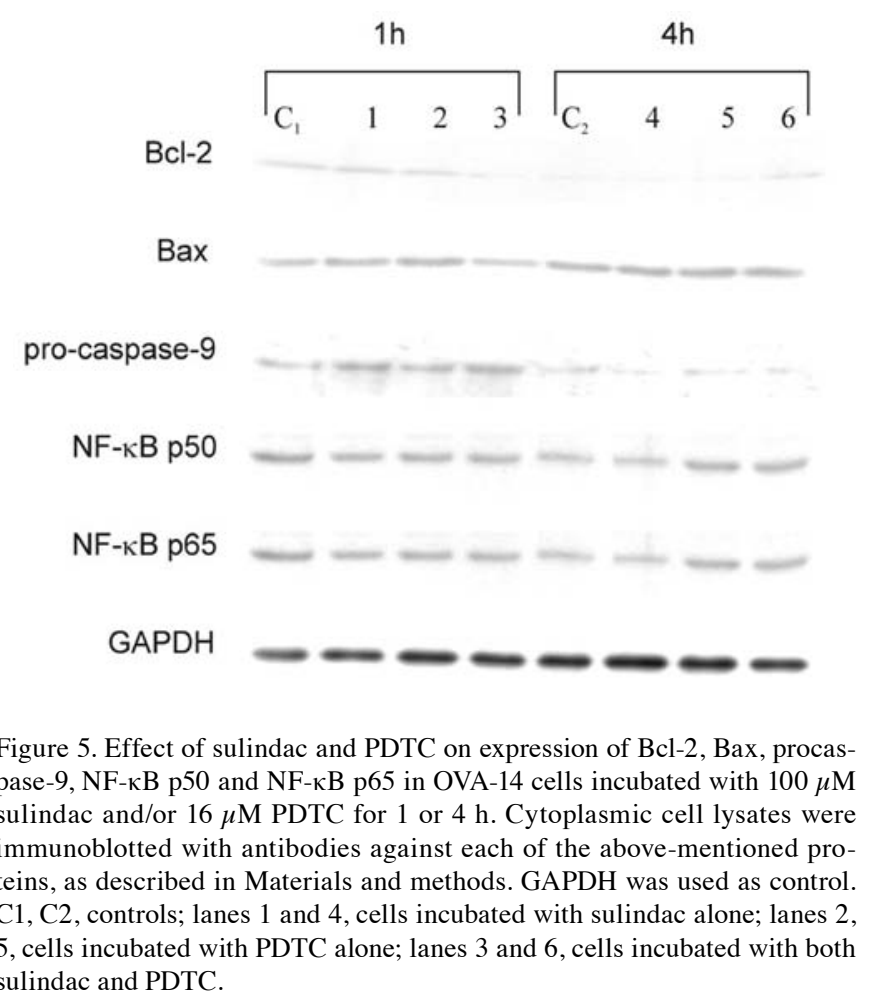
sulindac and PDTC.

tion for 4 or $24 \mathrm{~h}$, with subsequent Annexin-V flow cytometric analysis. There was a slight increase in the percentage of cells in early apoptosis [Annexin- $\mathrm{V}(+)$, propidium iodide(-) cells] in double-treated cultures in comparison with cells incubated with sulindac alone, PDTC alone or untreated cultures $(2.14 \%$, in comparison with $1.49,1.42$, and $1.44 \%$, respectively) at the 
4-h incubation timepoint (data not shown). In 24-h cultures, the process of apoptosis progressed and was especially exhibited in OVA-14 cells co-treated with sulindac and PDTC: $89 \%$ cells were found to be fully apoptotic, in comparison with $26 \%$ in sulindac cultures, $25 \%$ in PDTC cultures, and $8 \%$ in control cultures (Fig. 4). To shed some light on the intracellular mechanisms responsible for apoptosis progression in the cells co-incubated with sulindac and PDTC we examined, by Western blotting, the expression of various proteins that are characteristic of the apoptosis pathway. Cytoplasimc cell lysate proteins did not show any significant changes in the expression levels of Bax, NF- $\kappa \mathrm{B}$ p50, and NF- $\kappa \mathrm{B}$ p65, either in cells treated with sulindac and PDTC alone or in combination (Fig. 5). No effects of these two agents on NF- $\kappa \mathrm{B}$ and no NF- $\kappa \mathrm{B}$ DNA-binding activity were confirmed in an EMSA (data not shown). Western blot analysis revealed a decrease of antiapoptotic Bcl-2 protein after $1 \mathrm{~h}$ of incubation of OVA-14 cells with both agents and a drop of procaspase- 9 in single- and double-agent-treated cultures (Fig. 5). The latter observation argues for activation of caspase-9, which is typical for the downstream activation of the mitochondrial pathway of apoptosis.

\section{Discussion}

A combination approach of several therapeutic agents has become the standard treatment of ovarian cancer. In the present study, we demonstrated that the combined use of sulindac or sulindac sulfide and PDTC in vitro resulted in a synergistic cytotoxic effect against OVA-14 ovarian cancer cells (Fig. 1). This effect was also observed in our studies on other ovarian cancer cell lines (OVP-10, CAOV-1) (Fig. 2). The primary mechanism responsible for the cytotoxic effect of sulindac + PDTC was apoptosis (Fig. 4). Increased level of Bcl-2 and decreased expression of procaspase-9 (reciprocally proportional to the active form of caspase-9) argues for the mitochondrial apoptotic pathway and is in agreement with results of other investigators showing correlation of caspase-9 activation and cancer cell death following incubation with sulindac or sulindac sulfide (16) or PDTC (26). In our model, susceptibility of OVA-14 cells to the cytotoxic effect of sulindac and PDTC was not related to the expression of COX-1/COX-2 since both sulindac sulfide (an active inhibitor of cyclooxygenases in vitro) and sulindac (inactive compound) synergized with PDTC. Moreover, OVA-14 cells did not express COX-1 and COX-2 enzymes in our preliminary experiments (data not shown).

Both sulindac and PDTC have been shown to inhibit the prosurvival NF- $\kappa \mathrm{B}$ signaling pathway in different tumor models (29,34-36). However, interfering with the $N F-\kappa B$ pathway did not seem to play a role in the cytotoxic effect of sulindac and PDTC in our studies (Fig. 5). This observation does not exclude the possibility of $\mathrm{NF}-\kappa \mathrm{B}$ inhibition by sulindac and/or PDTC in case of activation of $N F-\kappa B$ in some circumstances, e.g. following standard chemotherapy (30) or in tumor cells with high constitutive expression of NF- $\kappa \mathrm{B}$. Recent results of Nai et al (37) argue for the latter scenario; they reported that application of PDTC in vivo led to a decreased level of NF- $\mathrm{B}$ (and also prevention of cachexia) in tumor tissue in a mouse model of colon cancer.
COX inhibitors, including sulindac and its metabolites, have been recognized as promising agents in the prevention of neoplasia and in cancer treatment, especially when combined with standard therapy [(38) and clinical trial NCT00755976). Several in vitro studies have shown their antitumor efficacy in ovarian cancer models $(10,13,19,23)$. On the other hand, PDTC has been reported to inhibit the growth of SKOV-3 ovarian cancer cells and to increase chemosensitivity of these cells to paclitaxel (30). Combination of sulindac and PDTC has not been tested before, to our knowledge, in any tumor model but, as shown in our investigation, their joined application seems very promising.

Apart from the direct pro-apoptotic activity of sulindac and PDTC, which we and others observed in vitro, these agents exert pleiotropic biological effects in vivo, beneficial from the therapeutic point of view. Upregulation of COX enzymes is a frequent feature of neoplasia and in ovarian cancers COXs have been implicated in platinum resistance and promotion of tumor progression $(11,12)$. Furthermore, taxanes, that are standard drugs used in first- and second-line therapy of ovarian cancer, have been shown to induce COX-2 expression (39). Therefore, one may expect that sulindac may increase the efficacy of these drug classes. Sulindac, alone or in combination with thalidomide, inhibited growth of carcinoma in rabbits (8) and was also effective in suppressing pancreatic tumor growth in a xenograft model in mice (14). Recently, sulindac in combination with epirubicin has been tested in patients with advanced cancers and stabilization of the disease in a patient with ovarian carcinoma was observed (38). Since PDTC, apart from potent $\mathrm{NF}-\kappa \mathrm{B}$ inhibitory properties and direct cytotoxic effect against tumor cells, manifests strong anti-angiogenic effects $(31,40)$, its addition to sulindac-based therapy could reveal stronger antitumor activity in vivo than those observed in ovarian cancer cell cultures in vitro. Thus, preclinical in vivo investigations of potential antitumor effect of PDTC and sulindac against ovarian cancers are worth continuing.

\section{References}

1. Gubbels JAA, Claussen N, Kapur AK, Connor JP and Patankar MS: The detection, treatment, and biology of epithelial ovarian cancer. J Ovarian Res 3: 8-11, 2010.

2. Pautier P, Joly F, Kerbrat P, Bougnoux P, Fumoleau P, Petit T, Rixe O, Ringeisen F, Tisseron Carrasco A and Lhomme C: Phase II study of gefitinib in combination with paclitaxel $(\mathrm{P})$ and carboplatin (C) as second-line therapy for ovarian, tubal or peritoneal adenocarcinoma (1839IL/0074). Gynecol Oncol 116: 157-162, 2010.

3. Pectasides D,Pectasides E,Papaxoinis G,Psyrri A,PliarchopoulouK, Koumarianou A, Macheras A, Athanasas G, Xiros N and Economopoulos T: Carboplatin/gemcitabine alternating with carboplatin/pegylated liposomal doxorubicin and carboplatin/ cyclophosphamide in platinum-refractory/resistant paclitaxelpretreated ovarian carcinoma. Gynecol Oncol 118: 52-57, 2010.

4. Ledermann JA and Raja FA: Targeted trials in ovarian cancer. Gynecol Oncol 119: 151-156, 2010.

5. Cuzick J, Otto F, Baron JA, Brown PH, Burn J, Greenwald P, Jankowski J, La Vecchia $\mathrm{C}$ and Meyskens F: Aspirin and nonsteroidal anti-inflammatory drugs for cancer prevention: an international consensus statement. Lancet Oncol 10: 501-507, 2009.

6. Akhmedkhanov A, Toniolo P, Zeleniuch-Jacquotte A, Kato I, Koenig KL and Shore RE: Aspirin and epithelial ovarian cancer. Prev Med 33: 682-687, 2001.

7. Sporn MB and Hong WK: Concomitant DFMO and sulindac chemoprevention of colorectal adenomas: a major clinical advance. Nat Clin Pract Oncol 5: 628-629, 2008. 
8. Verheul HMW, Panigrahy D, Yuan J and D'Amato RJ: Combination oral antiangiogenic therapy with thalidomide and sulindac inhibits tumour growth in rabbits. Br J Cancer 79 : 114-118, 1999

9. Uddin S, Ahmed M, Hussain A, Assad L, Al-Dayel F, Bavi P, Al-Kuraya KS and Munkarah A: Cyclooxygenase-2 inhibition inhibits PI3K/AKT kinase activity in epithelial ovarian cancer. Int J Cancer 126: 382-394, 2010.

10. Rodriguez-Burford C, Barnes MN, Oelschlager DK, Myers RB, Talley LI, Partridge EE and Grizzle WE: Effects of non-steroida anti-inflammatory agents (NSAIDs) on ovarian carcinoma cell lines: preclinical evaluation of NSAIDs as chemopreventive agents. Clin Cancer Res 8: 202-209, 2002.

11. Gupta RA, Tejada LV, Tong BJ, Das SK, Morrow JD, Dey SK and DuBois RN: Cyclooxygenase-1 is overexpressed and promotes angiogenic factor production in ovarian cancer. Cancer Res 63: 906-911, 2003

12. Munkarah A and Ali-Fehmi R: COX-2: a protein with an active role in gynecological cancers. Curr Opin Obstet Gynecol 17: 49-53, 2005.

13. Andrews P, Zhao X, Allen J, Li F and Chang M: A comparison of the effectiveness of selected non-steroidal anti-inflammatory drugs and their derivatives against cancer cells in vitro. Cancer Chemother Pharmacol 61: 203-214, 2008.

14. Yip-Schneider MT, Wu H, Ralstin M, Yiannoutsos C Crooks PA, Neelakantan S, Noble S, Nakshatri H, Sweeney CJ and Schmidt CM: Suppression of pancreatic tumor growth by combination chemotherapy with sulindac and LC-1 is associated with cyclin D1 inhibition in vivo. Mol Cancer Ther 6: 1736-1744, 2007.

15. Kunte DP, Wali RK, Koetsier JL and Roy HK: Antiproliferative effect of sulindac in colonic neoplasia prevention: role of $\mathrm{COOH}-$ terminal Src kinase. Mol Cancer Ther 7: 1797-1806, 2008.

16. Marotta A, Parhar K, Hundal R, Duronio V and Salh B: Differential targeting of protein kinase $B$ in cell death induced by sulindac and its metabolite sulindac sulfide. Int J Oncol 28 : 1471-1479, 2006

17. Karl T, Seibert N, Stohr M, Osswald H, Rosl F and Finzer P. Sulindac induces specific degradation of the HPV oncoprotein E7 and causes growth arrest and apoptosis in cervical carcinoma cells. Cancer Lett 245: 103-111, 2007.

18. Song Z, Tong C, Liang J, Dockendorff A, Huang C, Augenlicht LH and Yang W: JNK1 is required for sulindac-mediated inhibition of cell proliferation and induction of apoptosis in vitro and in vivo. Eur J Pharmacol 560: 95-100, 2007.

19. Kim JS, Baek SJ, Sali T and Eling TE: The conventional nonsteroidal anti-inflammatory drug sulindac sulfide arrests ovarian cancer cell growth via the expression of NAG-1/MIC-1/GDF-15. Mol Cancer Ther 4: 487-493, 2005.

20. Nikitakis NG, Hebert C, Lopes MA, Reynolds MA and Sauk JJ: PPAR $\gamma$-mediated antineoplastic effect of NSAID sulindac on human oral squamous carcinoma cells. Int J Cancer 98: 817-823, 2002.

21. Park JH, Kim EJ, Jang HY, Shim H, Lee KK, Jo HJ, Kim HJ, Yang SH, Jeong ET and Kim HR: Combination treatment with arsenic trioxide and sulindac enhances apoptotic cell death in lung cancer cells via activation of oxidative stress and mitogenactivated protein kinases. Oncol Rep 20: 379-384, 2008

22. Flis S and Spławiński J: Inhibitory effects of 5-fluorouracil and oxaliplatin on human colorectal cancer cell survival are synergistically enhanced by sulindac sulfide. Anticancer Res 29 : 435-442, 2009

23. Barnes AP, Miller BE and Kucera GL: Cyclooxygenase inhibition and hyperthermia for the potentiation of the cytotoxic response in ovarian cancer cells. Gynecol Oncol 104: 443-450, 2007.

24. Govindan R, Wang X, Baggstrom MQ, Burdette-Radoux S, Hodgson L, Vokes EE, Green MR and Cancer and Leukemia Group B: A phase II study of carboplatin, etoposide, and exisulind in patients with extensive small cell lung cancer: CALGB 3014. J Thorac Oncol 4: 220-226, 2009.
25. Sinibaldi VJ, Elza-Brown K, Schmidt J, Eisenberger MA Rosenbaum E, Denmeade SR, Pili R, Walczak J, Baker SD and Zahurak M: Phase II evaluation of docetaxel plus exisulind in patients with androgen independent prostate carcinoma. Am J Clin Oncol 29: 395-398, 2006.

26. Oh DH, Bang JS, Choi HM, Yang HI, Yoo MC and Kim KS: Fetal bovine serum requirement for pyrrolidine dithiocarbamateinduced apoptotic cell death of MCF-7 breast tumor cells. Eur J Pharmacol 649: 135-139, 2010.

27. Chen D, Peng F, Cui QC, Danie KG, Orlu S, Liu J and Dou QP: Inhibition of prostate cancer cellular proteasome activity by a pyrrolidine dithiocarbamate-copper complex is associated with suppression of proliferation and induction of apoptosis. Front Biosc 10: 2932-2939, 2005.

28. Chinery R, Brockman JA, Peeler MO, Shyr Y, Beauchamp RD and Coffey RJ: Antioxidants enhance the cytotoxicity of chemotherapeutic agents in colorectal cancer: a p53-independent induction of $\mathrm{p} 21 \mathrm{~W}^{\mathrm{AF} 1 / \mathrm{CIP1}}$ via C/EBP $\beta$. Nat Med 3: 1233-1241, 1997.

29. Morais C, Gobe G, Johnson DW and Healy H: Inhibition of nuclear factor kappa B transcription activity drives a synergistic effect of pyrrolidine dithiocarbamate and cisplatin for treatment of renal cell carcinoma. Apoptosis 14: 412-425, 2010.

30. Liu GH, Wang SR, Wang B and Kong BH: Inhibition of nuclear factor- $\mathrm{KB}$ by an antioxidant enhances paclitaxel sensitivity in ovarian carcinoma cell line. Int J Gynecol Cancer 16: 1777-1782, 2006.

31. Gu JW, Young E, Busby B, Covington J, Tan W and Johnson JW: Oral administration of pyrrolidine dithiocarbamate (PDTC) inhibits VEGF expression, tumor angiogenesis and growth of breast cancer in female mice. Cancer Biol Ther 8: 514-521, 2009.

32. Jakubowska-Mucka A, Sienko J, Switaj T, Golab J and Lasek W: Antitumor effects of sulindac in ovarian cancer cell cultures. Ginekol Pol 82: 195-199, 2011 (In Polish).

33. Chou TC and Talalay P: Quantitive analysis of dose-effect relationships: the combined effects of multiple drugs or enzyme inhibitors. Adv Enzyme Regul 22: 27-55, 1984

34. Seo AM, Hong SW, Shin JS, Park IC, Hong NJ, Kim DJ, Lee WK, Lee WJ, Jin DH and Lee MS: Sulindac induces apoptotic cell death in susceptible human breast cancer cells through, at least in part, inhibition of IKK $\beta$. Apoptosis 14: 913-922, 2009.

35. Yamamoto Y, Yin MJ, Lin KM and Gaynor RB: Sulindac inhibition activation of the NF- $\kappa$ B pathway. J Biol Chem 274: 27307-27314, 1999.

36. Nakanishi $\mathrm{C}$ and Toi M: Nuclear factor $\kappa \mathrm{B}$ inhibitors as sensitizers to anticancer drugs. Nature Rev Cancer 5: 297-309, 2005.

37. Nai YJ, Jiang ZW, Wang ZM, Li N and Li JS: Prevention of cancer cachexia by pyrrolidine dithiocarbamate (PDTC) in colon 26 tumor-bearing mice. JPEN J Parenter Enteral Nutr 31: 18-25, 2007.

38. O'Connor R, O'Leary M, Ballot J, Collins CD, Kinsella P, Mager DE, Arnold RD, O'Driscoll L, Larkin A, Kennedy S, Fennelly D, Clynes $\mathrm{M}$ and Crown J: A phase I clinical and pharmacokinetic study of the multi-drug resistance protein-1 (MRP-1) inhibitor sulindac, in combination with epirubicin in patients with advanced cancer. Cancer Chemother Pharmacol 59: 79-87, 2007.

39. Moos PJ, Muskardin DT and Fitzpatrick FA: Effect of taxol and taxotere on gene expression in macrophages: induction of the prostaglandin H synthase-2 isoenzyme. J Immunol 162: 467-473, 1999.

40. Morais C, Gobe G, Johnson DW and Healy H: Anti-angiogenic actions of pyrrolidine dithiocarbamate, a nuclear factor kappa B inhibitor. Angiogenesis 12: 365-379, 2009. 